\title{
Medullary Cystic Kidney Disease Type II
}

National Cancer Institute

\section{Source}

National Cancer Institute. Medullary Cystic Kidney Disease Type II. NCI Thesaurus. Code C123172.

An inherited form of cystic kidney disease leading to fibrosis and impaired renal function that is caused by mutations in the UMOD gene, which encodes uromodulin/TammHorsfall mucoprotein. 